\title{
PEMBARUAN HUKUM KELUARGA ISLAM: Studi Kasus Hukum Waris di Somalia
}

\author{
Ahmad Syafi'i SJ, Suad Fikriawan \\ Institut Agama Islam Sunan Giri Ponorogo \\ syafiiahmad79@gmail.com, suad.fikriawan@gmail.com
}

\begin{abstract}
This article aims to examine one of the phenomena that emerged in the Muslim world in the 20th century, namely the renewal of family law in Muslim-majority countries. This article focuses on the study of inheritance law reform in Somalia. By using a legal political approach, this article examines several important issues, i.e.,: the model of inheritance law reform in Somalia, the reasons that led to the revolutionary change from the concept of Islamic inheritance in general, and and the factors that influence these changes. In general, this study shows that in the reform of family law in Somalia, there are several rules that are not much different from the concept of the imam of the school of thought, but there are also several legal rules that are quite far from the conceot of conventional, especially the legal rules related to inheritance.
\end{abstract}

Keywords: Hukum Waris, Pembaruan, Somalia, Politik Hukum dan Sistem Peradilan

\section{PENDAHULUAN}

Hukum tentang perseorangan (personal status/al-ahwâl al-syakhshiyyah) merupakan bidang yang tidak hanya dianggap penting, tetapi juga dianggap yang paling fundamental dalam hukum Islam. Hal ini karena al-Qur'an menaruh perhatian besar terhadap persoalanpersoalan hukum yang berkaitan dengan keluarga, seperti perkawinan, perceraian, dan kewarisan, dari pada materi hukum lainnya. Oleh karena sangat fundamentalnya persoalan hukum yang berkaitan dengan masalah perseorangan, N.J. Coulson ${ }^{1}$ dan Esposito ${ }^{2}$

Press, 1964), 161.

${ }^{1}$ N.J. Coulson, A History of Islamic Law (Edinburgh: Edinburgh University

2 John L. Esposito, Women in Muslim Family Law (New York: Syracuse University Press, 2001), 12. 
mengemukakan bahwa hukum keluarga merupakan benteng hukum Islam. Dalam pengertian ini, hukum keluarga mempresentasikan suatu inti agama dan kaum muslimin pada umumnya menganggap bahwa mentaati prinsip-prinsip aturan ini sebagai suatu kriteria kepatuhan religius baik individu maupun kolektif. Oleh sebab itu, tampaknya cukup beralasan mengapa hukum Islam tentang personal status ini secara umum tetap berlaku di negara-negara Islam.

Setiap kali pemerintah negara-negara Islam berusaha melakukan reformasi dengan mengganti seluruh atau sebagian dari aspek hukum tersebut, selain Turki ${ }^{3}$ dan Tunisia, selalu gagal, tidak terkecuali Indonesia. ${ }^{4} \mathrm{Hal}$ ini disebabkan karena mendapatkan perlawanan yang keras dari ulama dan umat Islam di negara yang bersangkutan.

Akan tetapi, sejalan dengan proses perubahan ruang dan waktu, tampaknya mengacu pada versi hukum Islam produk abad pertengahan memerlukan peninjauan ulang bahkan reinterpretasi baru. Oleh karena itu, pembaharuan (reform atau ishlâh dan tajdîd) ${ }^{5}$ hukum Islam dalam bidang hukum keluarga merupakan suatu keniscayaan dan fenomena abad 20.6 Tuntutan pembaharuan ini dilatarbelakangi banyak faktor, di antaranya perubahan-perubahan sosio-kultural yang salah satunya adanya perubahan struktur keluarga yang komunalistik ke dalam bentuk nuclear family dan peningkatan peranan wanita (Islam) dalam kehidupan masyarakat.

3 J.N.D. Anderson, "Modern Trends in Islam: Legal Reform and Modernization in the Middle East," International and Comparative Law Quarterly, 20 Januari 1971, 6.

4 Zaini Ahmad Noeh, "Perkembangan Setelah Undang-Undang Perkawinan," Dalam Daniel S Lev, Peradilan Agama Islam di Indonesia: Suatu Studi Landasan Politik Lembaga-Lembaga Hukum (Jakarta: Intermasa, 1986), 339.

${ }^{5}$ Lihat Oxford Encyclopedia of Modern Islamic Law, Vol. 2, 242-464.

6 Salah satu fenomena yang muncul di dunia Muslim dalam abad 20 adalah adanya usaha pembaruan hukum keluarga (perkawinan, perceraian, dan warisan) di negara-negara berpenduduk mayoritas Muslim. Turki misalnya, melakukannya pada tahun 1917, Mesir 1920, Iran 1931, Syiria 1953, Tunisia 1956, Pakistan 1961, dan Indonesia tahun 1974. Lihat M. Atho' Mudzhar, dkk (eds.), Hukum Keluarga di Dunia Islam Modern: Studi Perbandingan dan Keberanjakan UU Modern dari Kitab-Kitab Fikih (Jakarta: Ciputat Press, 2003), 1. 
Di samping dua faktor tersebut, terdapat satu faktor yang menurut hemat saya sangat berpengaruh terhadap percepatan pembaharuan hukum Islam, yaitu adanya okupasi (occupation) wilayah-wilayah Islam oleh imperalis Barat di mana dalam praktiknya tidak hanya menguasai persoalan politik dan ekonomi, tetapi juga secara berlahan-lahan -jika tidak ingin dikatakan memaksakanmenciptakan perubahan hukum di wilayah itu dengan dalih bahwa sebagian hukum Islam sudah ketinggalan zaman.

Meskipun penjajahan, di satu sisi, telah mematikan potensi politik umat Islam secara umum, namun di sisi lain juga membuka kran yang lebih besar bagi masuknya arus modernisasi Barat. Kontak kaum muslimin dengan peradaban dan pemikiran Barat modern, sedikit banyak turut menentukan arah perkembangan negara-negara Muslim pada masa-masa selanjutnya, antara lain merangsang tumbuhnya kesadaran akan tertinggalnya masyarakat Islam, kadaluarsanya konsep-konsep pemikiran mereka, hingga kesadaran perlunya pembaruan demi kemajuan Islam. Salah satu aspek yang ikut tersentuh arus pembaruan tersebut adalah pemikiran dan pengembangan hukum keluarga Islam.

Somalia yang akan menjadi fokus pembicaraan meskipun baru mulai mengadakan pembicaraan pengembangan hukum keluarganya pada tahun 1972 yaitu dua belas tahun setelah negara tersebut merdeka pada tahun 1960 dan hukum keluarganya baru terbentuk secara resmi tahun 1975, namun reformasi hukum keluarganya nampak lebih revolusioner dibandingkan negara-negara lainnya bahkan setara dengan hukum keluarga negara sekuler Turki.

Secara lebih khusus, tulisan ini hendak membahas tentang bagaimana hukum waris di Somalia, mengapa terjadi perubahan revolusioner dari konsep kewarisan Islam secara umum, dan unsurunsur apa sajakah yang mempengaruhi perubahan tersebut. Untuk mengawali pembicaraan mengenai hukum keluarga di Somalia, ada baiknya penulis akan mengawalinya dengan membahas pembaruan hukum keluarga secara umum, kemudian dilanjutkan dengan 
melihat kesejarahan negara Somalia dari beberapa aspek seperti sosiologis, politik, budaya, kehidupan keagamaan, serta hukum waris dan reformasi materi kewarisan dalam hukum keluarga Somalia.

\section{PEMBARUAN HUKUM KELUARGA ISLAM: SURVEI KRONOLOGIS \\ Konsep Pembaruan}

Dalam literatur hukum Islam kontemporer, kata "pembaruan" silih berganti dipergunakan dengan kata reformasi, modernisasi, reaktualisasi, dekonstruksi, rekonstruksi, ishlâh dan tajdîd. Di antara katakata tersebut yang paling banyak dipergunakan adalah kata reformasi, ishlâh dan tajdîd. Reformasi berasal dari bahasa Inggris "reformation" yang berarti membentuk atau menyusun kembali.7 Reformasi sama artinya dengan memperbarui, asal kata "baru" dengan arti memperbaiki supaya menjadi baru atau mengganti dengan cara yang baru. ${ }^{8}$ Tajdîd mengandung arti membangun kembali, menghidupkan kembali, menyusun kembali atau memperbaikinya agar dapat dipergunakan sebagaimana yang diharapkan. ${ }^{9}$ Sedangkan kata ishlâh diartikan dengan perbaikan atau memperbaiki. ${ }^{10}$

Bustami Muhammad Saad ${ }^{11}$ mengemukakan bahwa kata tajdîd adalah lebih tepat digunakan untuk membahas tentang pembaruan hukum, sebab kata tersebut mempunyai arti pembaruan, sedangkan kata ishlâh meskipun sering digunakan secara berdampingan, tetapi lebih berat pengertiannya kepada pemurnian.

7 John M. Echol dan Hasan Shadily, Kamus Inggris-Indonesia (Jakarta: PT Gramedia, 2003), 473. Lihat juga Peter Collin, Dictionary of Law, Peter Collin Publishing, Third Edition, 2000, 311.

8 Depdikbud, Kamus Besar Bahasa Indonesia, cet. Ke-3 (Jakarta: PN Balai Pustaka, 1990), 82.

${ }^{9}$ Lois Ma'luf, Al-Munjid al-Abjadî (Beirût, Libanon: Dâr al-Masyriq, 1986), 229.

10 Lihat Ibid.

11 Bustami Muhammad Saad, Mafhûm Tajdîd al-Dîn al-Da'wah (Kuwait: tt.p. tt.), 26-27. 
Menurut Masjfuk Zuhdi ${ }^{12}$ kata tajdîd lebih komprehensif pengertiannya sebab dalam kata tajdîd terdapat tiga unsur yang saling berhubungan, yaitu: pertama, al-i'âdah, artinya mengembalikan masalah-masalah agama terutama yang bersifat khilafiah kepada sumber ajaran Islam yaitu al-Qur'an dan Sunnah. Kedua, al-ibânah, artinya purifikasi atau pemurnian ajaran agama Islam dari segala macam bentuk bid'ah dan khurafat serta pembebasan berfikir ajaran Islam dari fanatik mazhab, aliran, ideology yang bertentangan dengan prinsip-prinsip ajaran Islam. Ketiga, al-ihyâ', artinya menghidupkan kembali, menggerakkan, memajukan, dan memperbarui pemikiran dan melaksanakan ajaran Islam. Pembaruan yang dikemukakan ini berbeda dengan konsep pembaruan yang dikemukakan oleh Harun Nasution ${ }^{13}$ yang lebih menekankan kepada penyesuaian pemahaman Islam sesuai dengan perkembangan baru yang ditimbulkan akibat kemajuan ilmu pengetahuan dan teknologi modern.

Penggunaan kata tajdîd dalam membicarakan pembaruan hukum Islam didasarkan kepada al-Qur'an antara lain Surat Ibrâhim ((14): 19): "Kalau Allah menghendaki, maka Allah akan melenyapkan kamu dan mengganti dengan generasi yang baru." Demikian juga hadis riwayat Abû Daud "Sesungguhnya Allah akan membangkitkan untuk umat ini (umat Islam) pada setiap penghujung seratus tahun orang-orang yang memperbarui pemikiran agama mereka."14

Berdasarkan uraian di atas maka dapat dikatakan bahwa yang dimaksud dengan pembaruan hukum Islam (tajdîd) adalah suatu upaya dan perbuatan melalui proses tertentu dengan penuh kesungguhan yang dilakukan oleh mereka yang mempunyai kompetensi dan otoritas dalam pengembangan hukum Islam (mujtahid) dengan cara-cara yang telah ditentukan berdasarkan

12 Masjfuk Zuhdi, Pembaruan Hukum Islam dan Kompilasi Hukum (Surabaya: PTA Jawa Timur, 1995), 2-3.

13 Harun Nasution, Pembaruan Hukum Islam: Pemikiran dan Gerakan, cet. Ke-4 (Jakarta: Bulan Bintang, 1986), 11-12.

14 Al-Albani, Silsilah al-Hadîts al-Shahîh (Beirût-Libanon: al-Maktar al-Islâmî, 1972), 601. 
kaidah-kaidah istinbath hukum yang dibenarkan sehingga menjadikan hukum Islam dapat tampil dengan "performance" yang lebih segar dan modern, tidak ketinggalan zaman. ${ }^{15}$

\section{Pembaruan Hukum Keluarga di Dunia Islam}

Hukum keluarga dalam masyarakat Islam kontemporer, baik di negara-negara Islam maupun di negara-negara yang mayoritas penduduknya beragama Islam sangat menarik untuk dikaji. Sebab di dalam hukum keluarga tersebut terdapat jiwa wahyu ilahi dan sunnah Rasul. Dengan kata lain, bahwa hukum keluarga adalah inti dari syari'ah dan merupakan bidang utama dari hukum Islam yang masih menyisakan kekuatannyan untuk mengatur kehidupan umat Islam yang berjumlah lebih dari 800 Juta jiwa tersebar dari benua Afrika sampai Asia Tenggara. ${ }^{16}$

Sadar akan pentingnya posisi hukum keluarga dalam percaturan dunia, maka perlu diadakan pembaruan, pengembangan yang selaras dengan perkembangan zaman. Upaya ini dengan sadar telah dimulai sejak permulaan abad XX secara bertahap.

1. Tiga kategori negara Muslim

Negeri-negeri Muslim di dunia ini dalam kaitannya dengan reformasi hukum keluarga, pada dasarnya terbagi atas tiga kategori, yaitu: ${ }^{17}$

a. Negeri Muslim yang sama sekali tidak mau melakukan pembaruan dan masih tetap memberlakukan hukum

15 Bandingkan dengan Ahmad Rofiq, Pembaharuan Hukum Islam di Indonesia (Yogyakarta: Gama Media, 2001), 97.

16 John L. Esposito, Women in Muslim, X.

17 Tahir Mahmood, Family Law Reform in the Muslim World (Tripathi, Bombay: The Indian Law Institute, 1971), 3-8. Lihat juga J.N.D. Anderson, Islamic Law in the Modern World (New York: New York University Press, 1975), 82-83. Bandingkan dengan M. Atho Mudzhar, Fatwa-Fatwa Majlis Ulama Indonesia: Sebuah Studi tentang Pemikiran Hukum Islam di Indonesia 1975-1988 (Jakarta: INIS, 1993), 3; idem, Membaca Gelombang Ijtihad: Antara Tradisi dan Literasi ((Yogyakarta: Titian Ilahi Press, 1998), 174-75; juga Amir Mu'allim dan Yusdani, Konfigurasi Pemikiran Hukum Islam (Yogyakarta: UII Press, 2001), 7-15. 
keluarga sebagaimana yang tertuang dalam kitab-kitab fikih dari mazhab yang dianut seperti Saudi Arabia.

b. Negeri Muslim yang sama sekali telah meninggalkan hukum keluarga Islam dan sebagai gantinya mengambil hukum sipil Eropa (hukum sekuler), seperti Turki.

c. Negeri-negeri yang berusaha untuk mencapai kompromi antara kedua daerah hukum tersebut dengan menerima hukum sekuler dan memelihara syari'at pada waktu yang bersamaan, seperti Mesir, Yordania, Tunisia, Irak, Syiria, Indonesia dan lain-lain.

\section{Fase-fase pembaruan}

Secara garis besar gerakan pembaruan hukum keluarga di dunia Islam pada abad ke-20 ini dapat dibagi ke dalam tiga fase yaitu: ${ }^{18}$

a. Fase tahun 1915-1950

Pada periode ini tercatat turki memperbarui hukum keluarganya pada tahun 1915 dan 1917 yang kemudian terus berlaku untuk wilayah-wilayah jajahannya di Yordania, Libanon, Palestina dan Syiria. Mesir menyusul dengan memberlakukan undang-undang No. 25 tahun 1920, yang kemudian disusul dengan undang-undang No. 56 tahun 1923, undang-undang No. 25 tahun 1929, No. 77 tahun 1943 dan No. 71 tahun 1947. Gerakan tersebut kemudian diikuti oleh Sudan pada tahun

b. Fase tahun 1950-1971

Dengan berakhirnya perang dunia ke II, sejumlah negeri berpenduduk Islam di Asia dan Afrika menjadi negara merdeka. Sebagian negara itu bahkan mencantumkan Islam sebagai agama resmi dalam konstitusi. Selain utu kita juga menyaksikan lahirnya negara Pakistan, pecahan dari India. Kenyataan ini memberikan angin baru terhadap gerakan

18 Tahir Mahmood, Personal Law in Islamic Countries (New Delhi: Academy of Law and Religion, 1987), 3-7. 
pembaruan hukum keluarga Islam. Pada periode ini tercatat Yordania mengundangkan hukum keluarganya pada tahun 1951, Syiria tahun 1953, Tunisia tahun 1956, Maroko tahun 1958, Irak tahun 1959, Algeria tahun 1959, dan Pakistan tahun 1961 dan 1962. Iran pada tahun 1967 sekali lagi memperbarui hukum keluarganya. Sedangkan umat Islam Indonesia pada fase ini belum mempunyai undand-undang tentang hukum keluarga, meskipun Indonesia telah memperluas jurisdiksi Pengadilan Agama di Luar Jawa dan Madura untuk mengurusi perkara warisan.

c. Fase tahun 1971-sekarang

Pada fase ini tercatat sejumlah pembaruan hukum keluarga dilakukan oleh sejumlah negara. Pada tahun 1971 Afganistan dan Kuwait masing-masing memberlakukan hukum perkawinan dan kewarisan. Tahun 1972 dan 1973 Libya memperbarui hukum perkawinan, perceraian dan wakaf. Pada tahun 1974 dan 1975 Yaman selatan memperbarui hukum keluarganya, meskipun hanya sebentar. Indonesia dan Somalia memberlakukan undang-undang perkawinan pada tahun 1974. Syiria juga memperbaiki undang-undang yang dibuatnya tahun 1953 dan Iran memperbaiki lagi undang-undang yang dikeluarkan pada tahun 1967. Pada tahun 1976 dan 1977 Yaman utara melakukan kodifikasi hukum kewarisan dan Yordania memperbarui undangundang yang dibuatnya pada tahun 1951. Pada tahun 1978, Yaman utara memperbaharui lagi hukum keluarganya dan Irak memperbaiki hukum undang-undang tahun 1959. Pada tahun 1979-1980, Mesir memperbarui lagi undang-undang yang dikeluarkan pada tahun 1920 dan 1929. pada tahun 1981 Tunisia merombak undang-undang yang dibuatnya pada tahun 1956. Pada tahun 1983, Irak memberlakukan undang-undang tentang hak-hak wanita yang dicerai. Pada tahun 1984 dan 1985, Algeria memberlakukan hukum keluarga yang lebih komprehensif lagi, kemudian disusul 
dengan Mesir yang sekali lagi mereformasi hukum keluarga yang dibuat tahun 1920 dan 1929. Pada tahun 1986 dilakukan kodifikasi hukum keluarga di negara-negara Emirat Arab dan seperti kita ketahui pada tahun 1989 Indonesia memberlakukan undang-undang tentang Peradilan Agama.

\section{Tujuan pembaruan}

Adapun tujuan dari usaha pembaruan hukum keluarga berbeda antara satu negara dengan negara lain secara umum dapat dikelompokkan menjadi tiga. Pertama, dan merupakan kelompok umum, negara yang melakukan pembaruan hukum keluarga dengan tujuan untuk terciptanya unifikasi hukum. Usaha unifikasi ini dilakukan karena ada sejumlah mazhab yang diikuti di negara bersangkutan, yang boleh jadi terdiri dari mazhab-mazhab di kalangan Sunni, atau antara Sunnî dan Syî'î. Bahkan untuk kasus Tunisia unifikasi hukum ditujukan untuk semua warga negara tanpa memandang perbedaan agama. ${ }^{19}$ Tujuan kedua, adalah untuk meningkatkan status wanita.

19 Anderson misalnya menyatakan, bahwa UU Tunisia berlaku untuk semua warga Tunisia, khususnya setelah dicapai kesepakatan dengan Perancis pada tanggal 1 Juli 1957, termasuk Yahudi sejak tanggal 1 Oktober 1957, kecuali untuk kasus-kasus yang belum ada aturannya dalam undang-undang ini. Usaha unifikasi hukum ini minimal dapat dikelompokkan menjadi empat kelompok. Pertama, unifikasi hukum yang berlaku untuk seluruh warga negara tanpa memandang perbedaan agama, misalnya kasus yang berlaku di Tunisia. Kelompok kedua, unifikasi yang bertujuan untuk menyatukan dua aliran pokok dalam sejarah muslim, yakni antara paham Sunnî dan Syî' $\hat{1}$, di mana Iran dan Iraq termasuk dalam kategori ini, karena di kedua negara tersebut ada penduduk yang menganut kedua aliran tersebut. Ketiga, kelompok yang berusaha memadukan antar mazhab dalam Sunnî, karena di dalamnya ada pengikut mazhab yang bersangkutan. Dan keempat, unifikasi dalam satu mazhab tertentu, misalnya di kalangan pengikut Syâfi'î, Hanafî, atau Mâlikî. Dengan menyebut unifikasi dari antar mazhab, bukan berarti bahwa format pembaruan yang ditemukan dengan sendirinya beranjak dari dan berdasar pada mazhab yang ada di negara yang bersangkutan. Boleh jadi formatnya diambil dari pandangan mazhab yang tidak ditemukan sama sekali di negara yang bersangkutan. Sekedar contoh, Indonesia yang penduduk muslimnya mayoritas bermazhab Syâfi'î, bukan berarti format hukum keluarganya sesui dengan pandangan-pandangan Syâfi'î dan ulama Syâfi'"̂̀, tetapi boleh jadi malah mengadopsi dari pandangan mazhab Dzâhirî, atau Hanafî, dan lain sebagainya. Baca Anderson, "The Tunisian Law of Personal Status," dalam International and Comparative Law Quarterly, Vol. 7-April (1958), 266. 
Meskipun tujuan ini tidak disebutkan secara eksplisit, namun dapat dilihat dari sejarah munculnya, yang diantaranya untuk merespons tuntutan-tuntutan peningkatan status wanita. Undang-undang hukum keluarga Mesir ${ }^{20}$ dan Indonesia ${ }^{21}$ adalah contoh yang masuk dalam kelompok kedua ini. Tujuan ketiga, adalah untuk merespons perkembangan dan tuntutan zaman, karena konsep fikih tradisional dianggap kurang mampu menjawab problematika yang ada. Dari ketiga tujuan tersebut, dapat dikatakan bahwa tujuan ketiga ini merupakan tujuan mayoritas dari adanya pembaruan hukum keluarga Muslim, meskipun tidak menutup kemungkinan tercakupnya ketiga tujuan tersebut sekaligus di beberapa negara.

4. Sifat dan Metode Pembaruan

Tahir Mahmood mencatat, bahwa pada prinsipnya metode pembaruan yang digunakan dalam pembaruan hukum keluarga sama yang digunakan oleh para pembaru pada umumnya, yakni: (1) ijtihâd; (2) qiyâs deduktif; (3) ijmấ', ditambah dua teori baru, yakni: takhayyur dan talfî. Sebagai tambahan, untuk mencapai pembaruan hukum keluarga tersebut muncul fenomena: (1) adanya fenomena memperlakukan pandangan semua mazhab pada tingkatan yang sama, dan penekanan pada (2) istihsân; (3) mashlahah mursalah; (4) siyâsah al-syar'iyyah; (5) istidlâl dan yang semacamnya. ${ }^{22}$

Dalam karyanya yang lain Mahmood menjelaskan,,23 bahwa ada pula yang memperkenalkan (sifat) reformasi hukum yang

20 Lihat Mahmood, Family Law Reform, 35-36.

${ }^{21} \mathrm{Hal}$ ini dapat dilihat dari adanya tuntutan yang mencuat dari para wanita Indonesia, baik secara indifidu maupun lewat gerakan organisasi secara kolektif. Lihat Barbara N. Ramusack and Sharon Sievers, Women in Asia (Indianapolis: Indiana University Press, 1988), 100; Nurlena Rifai, "Muslim Women in Indonesia's Politics: An Historical Examination of the Political Career of Aisyah Aminy," Tesis MA (Montreal: McGill University, 1993), 32; juga Khoiruddin Nasution, Status Wanita di Asia Tenggara: Studi Terhadap Perundang-Undangan Perkawinan Muslim Kontemporer di Indonesia dan Malaysia (Jakarta: INIS, 2002), khususnya bab VII.

22 Tahir Mahmood, Personal Law, 13.

23 Tahir Mahmood, Family Law Reform, 267-269. 
pada dasarnya tertidiri atas dua macam, yaitu: (1) intra-doktrinal reforam, yaitu reformasi hukum keluarga Islam yang dilakukan dengan menggabungkan pendapat dari beberapa mazhab atau mengambil pendapat lain selain dari mazhab utama yang dianut; ${ }^{24}$ (2) extra-doctrinal reform, yaitu pembaruan hukum dengan cara memberikan penafsiran yang sama sekali baru terhadap nash yang ada. ${ }^{25}$

Anderson mencatat empat metode umum ${ }^{26}$ yang digunakan sarjana dalam melakukan pembaruan hukum keluarga Islam kontemporer, yakni: (1) lewat aturan yang bersifat prosedural sesuai dengan tuntutan zaman modern (bersifat administratif), yang dalam istilah lain disebut takhsî al-qadhấ/siyâsah alsyar'iyyah tetapi substansinya tidak berubah;27 (2) takhayyur ${ }^{28}$ dan talfíq; ${ }^{29}$ (3) ijtihâd dengan jalan menginterpretasi (reinterpretation)

24 Meskipun Turki adalah penganut mazhab Hanafi misalnya, tetapi UU tentang hak keluarga Turki tahun 1917 juga mengandung elemen-elemen dari mazhab lain. Apalaigi Irak, undang-undang hukum keluarga di negara ini jelas sekali mengandung unsur Sunni dan Syi'ah. Kompromi antar mazhab ini, menjadi salah satu model cara pembaruan hukum keluarga Islam.

25 Penerapan hukum sipil Barat oleh Turki diklaim oleh sebagian sarjana Turki bukan sebagai penyimpangan dari hukum keluarga Islam, melainkan sebagai hasil penafsiran baru terhadap pemahaman yang ada.

${ }_{26}$ Disebut metode umum, sebab Anderson mencatat metode khusus yang digunakan India dan negara-negara yang pernah dipengaruhi hukum Inggris. Lihat Anderson, Law Reform in the Muslim World (London: University of London the Athlon Press, 1976), 77 dst.

27 Misalnya aturan Mesir untuk mengurangi bahkan melarang perkawinan anak di bawah umur. Contoh lain Pegawai Pencatat Nikah dilarang mencatat perkawinan pasangan yang belum cukup umur minimal boleh nikah. Lihat Anderson, Law Reform, 46-47.

28 Takhayyur adalah suatu metode yurisprudensi yang karena dalam situasi spesifik dibolehkan meninggalkan mazhab hukumnya untuk mengikuti mazhab lainnya. Contoh dari aplikasi metode ini adalah aturan taklik thalak yang dicantumkan Turki dalam undang-undang tahun 1917 (Pasal 38), bahwa seorang isteri berhak mencantumkan taklik talak bahwa poligami suami dapat menjadi alasan perceraian. Ibid., 49.-51. Sementara untuk kasus Indonesia dapat dicontohkan dengan aturan tentang penghapusan hak ijbâr wali yang didasarkan pada pandangan Ibn Syubrumah.

29 Talfí adalah suatu metode mengkombinasikan berbagai mazhab untuk membentuk peraturan tunggal. Adapun aplikasi dari metode ini adalah dalam kasus warisan. Di antara contohnya adalah tentang status bagian saudara atau saudari karena ada kakek. Misalnya dalam hukum keluarga Sudan No. 49 tahun 1939, yang diikuti dengan undang-undang No. 51 tahun 1943 dan Mesir ditetapkan bahwa saudara atau 
teks syari'ah; ${ }^{30}$ (4) menggunakan alternatif, yakni menggunakan aturan administrasi, misalnya dengan memberikan sanksi bagi yang melanggar, tetapi tidak berdasarkan alasan syari' ah. ${ }^{31}$

Sementara itu David Pearl menyimpulkan, bahwasanya negara-negara Muslim menggunakan empat metode dalam melakukan pembaruab hukum keluarga, yaitu: (1) takhayyur; (2) talfìq; (3) siyâsah al-syar'iyyah; dan (4) murni memenuhi kebutuhan sosial dan ekonomi tanpa mendasarkan sama sekali terhadap alasan mazhab, yang oleh para pemikir lain disebut reinterpretasi terhadap nas sesuai dengan tuntutan zaman. ${ }^{32}$

\section{Format dan isi pembaruan}

Adapun bentuk pembaruan yang dilakukan berbeda antara satu negara dengan negara lain. Pertama, kebayakan negara melakukan pembaruan dalam bentuk undang-undang. Kedua, ada beberapa negara yang melakukannya dengan berdasar pada dekrit raja atau presiden, seperti Yaman Selatan dengan dekrit raja tahun 1942, dan Syiria dengan dekrit presiden tahun 1953. Ketiga, ada negara yang usaha pembaruannya dalam bentuk

saudari tetap mendapat bagian warisan dengan jalan berbagi (sharing) dengan kakek. Padahal menurut pendapat Abu Hanîfah (Abû Yûsuf dan al-Syaibanî), yang juga diikuti oleh Syâfi'î dan Mâlik, saudara/saudari kandung atau sebapak tidak mendapat bagian dengan adanya kakek. Ketetapan Sudan dan Mesir ini didasarkan pada perpaduan pandangan Zaid bin Tsâbit yang menetapkan bahwa saudara/saudari demikian tidak dengan sendirinya tidak mendapat bagian, dengan pandangan 'Alî bin Abî Thâlib yang berpendapat bahwa saudara/saudari seayah tetap mendapat bagian bersama kakek. Baca Ibid., 55-56.

$30 \mathrm{Di}$ antara contohnya adalah (a) aturan tentang poligami yang diusulkan panitia Mesir bahwa untuk boleh poligami harus dengan izin Pengadilan dengan syarat harus dapat berbuat adil kepada para istri dan mampu mencukupi kebutuhan rumah tangga; (b) larangan poligami oleh Tunisia. Lihat Ibid., 62-63. Pembahasan tentang reinterpretasi nash ini dapat dilacak dalam Ibid., 58-65.

31 Pembahasan lebih detail baca Anderson, Law Reform, 42-77. Baca juga Esposito, Women in Muslim Family Law (Syracus: Syracus University Press, 1982), 94-102.

32 Contoh dengan metode terakhir adalah pengharaman poligami, yang didasarkan pada penafsiran baru surat an-Nisâ' (4): 3, bahwa keadilan yang dibutuhkan untuk bolehnya poligami bukan hanya dalam aspek nafkah, tetapi juga termasuk rasa cinta dan kasih saying. Karena itu menurut Pearl, ada keberanjakan dari esensi hukum Islam.Lihat David Pearl dan Werner Menski, Muslim Family Law, edisi ke-3 (London: Sweet \& Maxwell, 1998), 21-22. 
ketetapan-ketetapan hakim (manshûrât al-qâdhi al-qudhât), seperti yang dilakukan Sudan. ${ }^{33}$

Sementara itu, dalam perspektif sejarah, pembaruan hukum Islam menurut Noel J. Coulson, menampakkan diri dalam empat bentuk atau model: (1) dikodifikasikannya (yaitu pengelompokan hukum yan sejenis ke dalam kitab undangundang) hukum Islam menjadi hukum perundang-undangan negara, yang disebut dengan doktrin siyasah; (2) tidak terkaitnya hanya pada satu mazhab hukum tertentu, yaitu disebut doktrin takhayyur (seleksi pendapat mana yang paling dominan dalam masyarakat); (3) perkembangan hukum dalam mengantisipasi peristiwa hukum yang baru timbul, yang disebut dengan doktrin tathbîq (penerapan hukum terhadap peristiwa baru); (4) perubahan hukum dari yang lama kepada yang baru yang disebut dengan doktrin tajdîd. ${ }^{34}$

Dari sisi isinya, menurut penelitian Tahir Mahmood, ada tiga belas aspek dalam undang-undang keluarga Muslim kontemporer yang mengalami pembaruan, yakni: (1) masalah batasan umur minimal boleh kawin; (2) pembatasan peran wali dalam perkawinan; (3) keharusan pencatatn perkawinan; (4) kemampuan ekonomi dalam perkawinan; (5) pembatasan kebolehan poligami; (6) masalah nafkah isteri dan keluarga; (7) masalah talak dan cerai di muka pengadilan; (8) masalah hakhak wanita yang dicerai suaminya; (9) masalah masa kehamilan dan implikasinya; (10) hak wali orang tua; (11) hak waris keluarga dekat; (12) wasiat wajibah; dan (13) masalah perwakafan. ${ }^{35}$ Sejumlah negara melakukan pembaruan hukum keluarga secara menyeluruh, sementara itu sejumlah negara yang lain membatasi hanya pada perkawinan dan perceraian.

${ }^{33}$ Lihat Atho Muzdhar, dkk (ed.), "Pendahuluan," dalam, Hukum Keluarga di Dunia Islam, 1-2.

34 N.J. Coulson, A History of Islamic Law (Edinburgh: Edinburgh University Press, 1994), 145-185.

35 Tahir Mahmood, Personal Law in Islamic, 11-12. 
Bahkan ada negara yang melakukan pembaruan dengan cara setahap demi setahap.

\section{Sosio-Kultural dan Sejarah Somalia: Legal History, School of Fiqh, and Constitutional Status of Islamic Law.}

Somalia merupakan sebuah negara republik, yang hampir seluruh penduduknya beragama Islam. Islam terbesar di Somalia sejak ababd pertama Hijrah melalui kontak perdagangan. ${ }^{36}$ Negara ini berada di Benua Afrika di sepanjang lautan India, di sebelah timur berbatasan dengan lautan India, sebelah utara dengan teluk Aden, sebelah barat dengan Ethiopia dan Kenya serta sebelah selatan dengan lautan Indian. Pada tahun 1983 penduduk Somalia berjumlah 6.248.000, dengan penduduk muslim hampir mencapai 100\%, di samping warga Inggris, Itali dan Kristen yang kurang dari 1\%. Bahasa yang digunakan adalah bahasa Somalia dan bahasa Arab. Bangsa Somalia berasal dari suku Arab dan Quraisy yang pindah pada sekitar abad ke tujuh. ${ }^{37}$ Muslim Somalia mayoritas adalah Sunni yaitu penganut mazhab Syâfi'î. ${ }^{38}$ Karena loyalitas mereka terhadap Islam, maka mereka masih membedakan tetangga mereka yang beragama Kristen, ataupun yang masih setia menganut kepercayaan asli Afrika. ${ }^{39}$ Somalia juga dikenal sebagai pemilik tradisi lisan yang sangat kaya, yang dijaga kelestariannya secara dihafal tidak secara dicatat. ${ }^{40}$

Dalam kehidupan beragama, mereka amat dipengaruhi oleh empat ajaran aliran Sufi, yaitu: Qadariyah, Ahmadiyah, Salihiyah, dan Rifa'iyah. Sebagai contoh, dalam kehidupan budaya diharamkan

36 Cyril Glasse, "Somalia," dalam Ensiklopedi Islam, terj. Ghufran A. Mas'adi (Jakarta: PT Raja Grafindo Persada, 1999), 368.

37 Inamullah Khan (ed.), The World Muslim Gazetter, cet. Ke-4 (Delhi: International Islamic Publisher, 1992), 578.

38 Abdullah A. An-Na'im (ed.), Islamic Family Law in a Changing World: A Global Resource Book (New York: Zed Book Ltd, 2002), 80. Baca juga H.A.R. Gibb, dkk (eds.), "Somaliland", dalam E.J. Brill's First Encyclopedia of Islam 1913-1936, Vol. VII (Leiden \& New York: Kobenhavn, Koln, 1987), 486.

${ }^{39}$ C. RWS. Hudson, "Religiuos Life" dalam http Somalia.

40 Glasse, "Somalia," dalam Ensiklopedi Islam, 368. 
pembuatan topeng. ${ }^{41}$ Disamping itu, Islam di Somalia masih memasukkan unsur-unsur budaya pra Islam, seperti penganut pemujaan terhadap hujan yang dianggap melindungi anak-anak kecil. Masyarakat adat Somalia dibagi menjadi dua, yaitu orangorang beragama (wadaad) dan para pejuang atau prajurit (warrior). Kelompok beragama diharapkan dmenjadi penengah konflik, maka mereka menghindari kehidupan politik. Sedangkan kelompok warrior-lah yang berperan dalam perpolitikan negara.

Pada masa kolonialis, Islam di Somalia bersifat defensif sejak abad 19 dan 20. Pada abad 19, beberapa daerah teritorial Somalia diduduki oleh Inggris, Italia, dan Dinasti Mamalik Abbasiayah. Hal ini menyebabkan munculnya kelompok Islam revivalis radikal yang dipimpin oleh Sayyid Mohammed Abdille Hassan dari tahun 18991920. Gerakan ini pada awalnya berusaha menjadi penengah antar klan dan menyerukan anti kolonialisme.

Pengikut gerakan ini sejak tahun 1920 sampai 1930 berubah menjadi gerakan reformisme dari pimpinan dua modernis Islam yaitu Haji Farah Omar di daratan Somalia dan Maalim Jama di Mogadishu. Haji Farah Omar membentuk Assosiasi Islam Somalia, yaitu sebuah organisasi kultural yang melakukan perbaikan di bidang pendidikan Islam dengan memasukkan aspek pendidikan Barat. Di sisi lain, kelompok nasionalis Somalia tetap berpandangan sekuler walaupun telah muncul para pemimpin yang berlatar belakang religious. Bahkan para pendiri partai nasionalis selatan, Liga Pemuda Somalia condong kepada Nasseria dan Islam sosialis.

Republik Somalia menganut sistem parlemen multipartai antara tahun 1960 sampai 1969. Isu-isu Islamisasi menjadi nomor dua, selain isu tentang pemberlakuan tulisan Arab Utsmani menjadi tulisan resmi Somalia baikdalam administrasi kenegaraan maupun bidang pendidikan. Sejak masa ini para pemimpin Islam tertarik

${ }^{41}$ Habib, "Hukum Keluarga Islam Negara Somalia," dalam Atho' Muzdhar, dkk (ed.), Hukum Keluarga di Dunia Islam, 155. Lihat juga Glasse, "Somalia," dalam Ensiklopedi, 368. 
untuk melihat produksi pertanian dan mencoba mengorganisasikan para petani di tingkat grassroot.

Pada tahun 1969, Jendral Mohammed Siyad Barre melakukan kudeta dan memulai rezim baru dengan suatu program reformasi hukum yang berdasarkan pada sosialisme ilmiah (scientific sosialism) sebagai ideologi negara. ${ }^{42}$ Tulisan latin dijadikan tulisan resmi negara Somalia. Sistem militer diktator yang diadopsi dari Soviet diberlakukan secara represif terutama terhadap agama. Pada tahun 1975, Barre mengeksekusi para pemimpin agama karena protes damai yang mereka lakukan terhadap pemberlakuan hukum keluarga dan perkawinan yang baru yang dianggap menyimpang dari peraturan Islam. Kemudian negara mengatur masalah ibadah sholat, puasa, pakaian keagamaan dan sebagainya. Para pelajar yang memakai pakaian Muslim (jilbab) pernah dipenjara. Tahun 1989 sampai tahun 1990, tentara Barre membantai ratusan pemimpin agama dan para pengikutnya. Seakan Islam lebih aman di bawah pemerintah kolonialis dari pada di bawah pemerintahan diktator ini.

Pada tanggal 15 Mei tahun 1990, ratusan pemimpin politik dan para pegawai membuat isu yaitu sebuah manifesto yang menuntut Barre untuk meletakkan jabatannya. Para pemimpin agama juga mengajukan tuntutan yang disebut "seruan Islam" pada 7 Oktober 1990. Seruan tersebut menerima demokrasi parlementer secara umum bahkan menuntut adanya institusi syura Islam. Barre jatuh pada Januari 1991 yang diikuti dengan terjadinya chaos, perang civil, kejahatan-kejahatan, dan sejenisnya yang membawa pendudukan PBB di bawah pimpinan Amerika Serikat pada Desember 1992.

Kebangkitan Islam menjadi semakin menyedihkan, meskipun terdapat kelompok Islam fundamentalis yang berasal dari gerakan tentara, namun mereka tidak mempunyai sosok pemimpin yang kharismatik, maka sistem klan tetap berlaku menentang Islam

42 An-Na'im (ed.), Islamic Family Law, 79. 
radikal. Gerakan fundamentalis Islam Somalia al-Ittihat al-Islam (Islamic Unity) yang aktif di bagian Somalia utara. ${ }^{43}$

Pada tahun 1979, Islam oleh pemerintah Somalia didkarasikan sebagai agama resmi negara tersebut (Pasal 3, Bab 1 Undang-undang tahun 1979). ${ }^{44}$

\section{POLITIK HUKUM SOMLAIA}

Pada masa kolinial, di Somalia berlaku hukum Inggris (abad 19-20). Inggris memberlaukan Peradilan Adat, ordonansi perkawinan tahun 1928 dan ordonansi Peradilan Qadi tahun 1937. Kemudian dikeluarkan ordonansi peradilan rendah tahun 1944 yang mencabut ordonansi tahun 1937, yang membatasi jurisdiksi peradilan qadi hanya dalam materi status personal. Sedangkan di bawah kekuasan Itali, yaitu di daerah Somalia selatan, masih mengembangkan sistem peradilan qadi yang memiliki jurisdiksi perkara perdata (civil) dan pidana ringan. ${ }^{45}$

Setelah masa kemerdekaan yaitu tahun 1960, Somalia yang mempunyai empat tradisi hukum yang berbeda yaitu: common law Inggris, hukum Italia, hukum Islam (syari'ah), dan hukum adat Somalia, berusaha menjadikan warisan hukum yang berbeda-beda tersebut menjadi satu sistem. Oleh karena itu, dilakukan penyeragaman kodifikasi hukum pidana dan acara pidana serta dilakukan regulasi terhadap organisasi peradilan, dengan mengadopsi sitem hukum Italia yang berdasarkan kepada penerapan putusan peradilan (presedent) 46 dan interpretasi tehadap hukum kodifikasi, serta menetapkan comman law Inggris dan doktrin equity ${ }^{47}$

43 Disarikan dari John L. Esposito (ed.), The Oxford Encyclopedia of the Modern Islamic World (New York: Oxford University Press, 1999), 91-92.

44 An-Na'im (ed.), Islamic Family Law, 80.

45 Ibid., 79.

46 Hakim memutuskan perkara berdasarkan keputusan hakim sebelumnya. Hal ini terdapat dalam sistem hukum common law.

47 Equity adalah norma-norma hukum yang pada abad ke-13 dan diterapkan oleh badan court of charity yang berfungsi melengkapi kekurangan-kekurangan comman law dan mengadakan koreksi terhadapnya. Timbulnya equity disebabkan karena comman 
dalam masalah-masalah yang tidak diatur dalam legislasi. Hukum Islam yang berlaku hanya sebatas pada perkara perkawinan, perceraian, perselisihan keluarga, dan warisan. Sementara hukum adat Somalia diterapkan secara opsional dalam beberapa perkara yaitu pertanahan, air, hak penanaman, dan pembayaran diyat. ${ }^{48}$

Sejak tahun 1972, telah dirancang reformasi hukum keluarga berdasarkan kebijakan pemerintah sosialis. Untuk itu, telah dibentuk suatu komisi guna mempersiapkan draf hukum keluarga yang baru tersebut. Pada tahun 1975, baru diundangkan hukum keluarga Somalia (Family Code of Somalia). Sebagai ketua pembentuk hukum keluarga tersebut adalah Abdisalem Syeikh Hussain, sekretaris negara bidang Pengadilan dan Urusan Agama Pemerintah Somalia, bersama-sama dengan Siad Barre. Tujuan utama dari perundangan baru ini adalah untuk menghapus bentuk hukum adat (to abolish customary law) yang dianggap sebagai tantangan pemerintahan baru Barre. ${ }^{49}$ Ia membatasi pengaruh klan dalam penerapan hukum dan sanksi adat serta menghapuskan klan-klan tradisional dan menghapus hak klan dalam hal penguasaan tanah, sumber air dan hak penanaman.

Hukum keluarga tahun 1975 tersebut terdiri dari dari 173 pasal yaitu mencakup:

(1) Masalah perkawinan dan perceraian, meliputi: kontrak (perjanjian) nikah, muhrim dalam pernikahan, pernikahan terhadap wanita kedua, usia perkawinan, pelarangan perkawinan, perwalian nikah, pembatalan perkawinan, mahar, nafkah, talak, penetapan kematian dan 'iddah.

(2) Masalah anak dan nafkah, meliputi: peran bapak, peran ibu, tanggung jawab bapak, pengasuhan anak, dan nafkah.

law dalam memberikan putusannya tidak dapat memuaskan para pencari keadilan, bahkan dalam bebeapa hal tidak mampu mengadilinya, sehingga mereka mencari kesempatan untuk meminta keadilan dari pihak pimpinan greja/agamawan (Lord Chancellor). R.Soeroso, Perbandingan Hukum Perdata (Jakarta: Sinar Grafika, 1993), 90-91.

${ }^{48}$ Lihat $h$ ttp Somalia

Law, 79.

${ }^{49}$ Lihat Tahir Mahmood, Personal Law, 254. Juga An-Naim (ed.), Islamic Family 
(3) Masalah perwalian, pengawasan dan perwakilan wali, pengajaran dan perwakilan, perlindungan terhadap person yang tidak cakap hukum, person yang cacat, kematian, dan adopsi.

(4) Peralihan harta, meliputi: wasiat dan kondisinya, pembatalan wasiat, penerimaan dan penolakan wasiat, obyek wasiat, prinsip-prinsip kewarisan, bagian-bagian waris, halangan kewarisan, dan ketetapan-ketetapan penutup.

Disamping itu, pasal dalam undang-undang 1975 tersebut menyediakan kemungkinan bahwa peraturan yang belum tercantum dalam perundangan tersebut akan didasarkan kepada: (1) pendapat dominan dari mazhab Syâfi'î; (2) prinsip-prinsip umum hukum Islam dan keadilan sosial. ${ }^{50}$

\section{SISTEM PERADILAN (Court System)}

Setelah merdeka, pengadilan syaria'h dan adat secara formal telah dikenal sebagai pengadilan-pengadilan Qadi. Peran judicial dari pengadilan tersebut sangat minim dan jurisdiksinya sangat terbatas pada masalah-masalah perdata (civil matters) seperti pernikahan dan perceraian.

Konstitusi tahun 1961 telah menetapkan suatu unifikasi peradilan yang independen dari pihak eksekutif dan legislatif. Pada tahun 1962 dilakukan penyatuan pengadilan Somalia utara dan Somalia selatan dengan pembagian empat sistem pengadilan, yaitu: Pengadilan Tinggi (supreme Court), Pengadilan Tingkat Banding (Courts of Appeal), Pengadilan Regional (Regional Courts) dan Pengadilan Distrik (District Courts). Pengadilan-pengadilan syari'ah (qadi) tidak diberlakukan walaupun dalam memutuskan perkara hakim mendasarkan pada syari' ah sebagai pertimbangannya.

Peradilan tingkat paling rendah adalah Pengadilan Distrik (terdiri dari 84 distrik) yang masing-masing dibagi menjadi divisi 
pidana dan perdata. Divisi pidana menangani masalah kriminal dan hukumnya, sedangkan divisi perdata mempunyai jurisdiksi tentang perkara gugatan, sekitar 3000 shilling Somalia. Para hakim diarahkan untuk menjadikan syari'ah dan hukum adat sebagai pertimbangan dalam mengambil keputusan.

Pengadilan Regional (terdiri dari 8 regional) masing-masing mempunyai tiga divisi yaitu: divisi pidana dan perdata yang menangani kasus-kasus besar, dan divisi yang menangani kasus perburuan. Adapun Pengadilan Tingkat Banding mempunyai dua divisi yaitu divisi biasa yang menangani banding dari putusan pengadilan distrik dan putusan perkara biasa pengadilan regional. Pengadilan Tingkat Tinggi berkedudukan di Mogadishu, mempunyai otoritas tertinggi dalam penyeragaman interpretasi terhadap hukum. Pengadilan ini menangani banding dari putusan pengadilan tingkat di bawahnya. ${ }^{51}$

\section{Materi Hukum Waris Somalia}

Materi kewarisan dalam hukum keluarga No. 23 tahun 1975 mengalami perubahan yang drastis -terutama dalam hal pembagian waris- dari sistem kewarisan Islam secara umum maupun dari mainstream mazhab yang berkembang. Di antara pasal-pasal yang mengandung materi waris dalam hukum keluarga tahun 1975 adalah sebagai berikut:

1. Pasal 158: Untuk menyesuaikan prinsip-prinsip Piagam Revolusi pertama dan kedua, laki-laki dan perempuan mempunyai hak yang sama dalam warisan.

2. Pasal 159: Ahli waris yang mendapatkan warisan adalah pasangan yang masih hidup, anak-anak, cucu dengan jenis kelamin apapun, ayah, kakek, ibu, nenek, saudara laki-laki dan perempuan sekandung, seayah dan seibu.

3. Pasal 160 (1): Pasangan yang masih hidup akan mendapat setengan dari harta peninggalan jika tidak anak atau cucu. Jika

51 Disarikan dari artikel sub judul "courts" dalam http Somalia; lihat juga AnNa'im, Islamic Family Law, 80. 
ada anak atau cucu, maka akan mendapat seperempat dari harta peninggalan. Jika ada lebih dari satu janda, maka bagian setengan atau seperempat akan dibagi sama rata.

Pasal 160 (2): Jika ahli waris yang berhak mendapatkan harta warisan adalah pasangan yang masih hidup, ibu, bapak, maka pasangan tersebut akan mendapat setengah, dan sisanya akan dibagi kepada orang tua dengan sama rata.

4. Pasal 161: Jika yang meninggal hanya mempunyai seorang anak laki-laki atau perempua, maka ia akan mendapat seluruh harta peninggalan. Jika ada dua atau lebih anak laki-laki atau perempuan, maka harta dibagai di antara mereka sama rata tanpa melihat jenis kelamin. Jika tidak ada anak melainkan ada cucu baik laki-laki atau perempuan, harta akan dibagai di antara mereka dengan bagian yang sama.

5. Pasal 162: Jika yang meninggal hanya mempunyai bapak, maka dia akan mendapat seluruh harta peninggalan. Jika terdapat anak atau cucu, bapak mendapat seperenam dan sisanya akan dibagi sama rata kepada anak-anak dan cucu. Kakek dapat mewarisi jika bapak tidak ada atau menempati kedudukan bapak.

6. Pasal 163: Jika orang yang mninggal hanya mempunyai ibu, maka dia akan mendapatkan seluruh harta peninggalan. Jika ada anak-anak atau cucu, maka ibu akan mendapat seperenam dan anak-anak atau cucu akan mendapat bagian sama rata dari sisa harta peninggalan. Nenek akan mendapat warisan dengan menempati kedudukan ibu.

7. Pasal 164: Jika yang meninggal hanya mempunyai seorang saudara laki-laki atau perempua, dia akan mendapatkan seluruh harta warisan. Jika ada dua atau lebih saudara laki-laki atau perempuan, maka harta peninggalan akan dibagi di antara mereka dengan sama rata. Jika ada kakek atau nenek, maka mereka mendapat seperenam dari harta peninggalan dan sisanya dibagi sama rata kepada saudara baik laki-laki atau perempuan. 
8. Pasal 167: Ayah dan ibu akan menghijab kakek atau nenek dengan jalur ayah dan ibu.

9. Pasal 168: Saudara laki-laki atau perempuan akan terhijab oleh ayah, ibu, dan anak-anak atau cucu.

10. Pasal 169: Anak-anak akan menghijab cucu, dan anak-anak atau cucu akan mengurangi bagian dari pasangan, ayah atau kakek, dan ibu atau nenek.

\section{Reformasi Hukum Waris Somalia: Sebuah Catatan Analisis}

Hukum adalah aturan-aturan normatif yang mengatur pola prilaku manusia. Hukum tidaklah tumbuh di ruang vakum, melainkan tumbuh dari kesadaran masyarakat yang membutuhkan adanya suatu aturan bersama. ${ }^{52}$ Oleh karena itu, hukum seharusnya berkembang sehingga dapat mengadopsi nilai-nilai yang di masyarakat, termasuk nilai-nilai adat, tradisi dan agama. Inilah yang dimaksudkan dengan kaidah al-'âdah al-muhakkamah (tradisi lokal dapat dijadikan acuan suatu hukum) dalam teori hukum Islam. ${ }^{53}$ Konsekuensinya, setiap produk hukum harus dilihat sebagai produk zamannya yang sulit melepaskan diri dari berbagai pengaruh yang melingkupi kelahirannya, baik pengaruh sosio-kultural maupun pengaruh sosio-politis. Sebagai produk sosial dan kultural, bahkan juga produk politik yang bernuansa ideologi, hukum idealnya selalu bersifat kontekstual.

Dalam konteks modern, hukum Islam cenderung mengikuti pengertian hukum sebagaimana dipahami di dunia Barat sekuler, terutama setelah munculnya nation-state. ${ }^{54}$ Hukum Islam tidak lagi

52 Siti Musdah Mulia, "Menuju Hukum Perkawinan Yang Adil: Memberdayakan Perempuan Indonesia," dalam Sulistyowati Irianto (ed.), Perempuan dan Hukum: Menuju Hukum yang Berspektif Kesetaraan dan Keadilan (Jakarta: Yayasan Obor Indonesia, 2006), 131.

53 Jalaluddin al-Suyuthi, al-Asybâh wa al-Nadhâir (t.tp.: t.th.), 63.

54 Untuk sejarah mmunculnya konsep dan realisasi natioan state, baca Rupert Emerson, From Empire to Nation: The Rise to Self-Assertaion of Asian and African People (Boston: Beacon Press, 1963); Benedict Anderson, Imagined Community: Reflections on the Origins and Spread of Nationalism (London: Verso, 1983); Rashid Khalid, et.al., ed. The Origins of Arab Nationalism (New York: Colombia University Press, 1991). 
dipahami sebagai fiqh seperti masa klasik dan tengah yang begitu luas mencakup semua aspek, tetapi dipahami secara terbatas yaitu "aturan-aturan yang ditentukan melalui lembaga tertentu dan dengan sanksi yang tertentu dan jelas pula." Ketentuan atau aturan yang tidak disertai dengan sanksi yang jelas dan konkrit di dunia ini tidak lagi menjadi wilayah hukum Islam. Dan hal ini amat berbeda dengan fiqh, masa klasik dan tengah yang mencakup keduanya: ada sanksi tegas di dunia atau tidak ada sanksi (sanksi berupa dosa di akhirat). Hukum pada masa modern tidak lagi menjadi wilayah religious authority tetapi wilayah political authority. Fenomena Kodifikasi $^{55}$ dan unifikasi Hukum Islam menjadi bukti konkrit akan hal ini, yang pada masa klasik dan tengah hampir-hampir tidak dikenal. Hukum bukan lagi menjadi wilayah ulama yang harus diikuti umara, tetapi sebaliknya menjadi wilayah umara dimana ulama ulama harus tunduk terhadapnya.

"it is for the state to select what rules to put in law codes and thereby to ditermine what the law is, and that one, unitary legal standart should prevail throughout a state's territory." 56 Jika pada masa klasik dan tengah berlaku tidaknya suatu hukum lebih banyak bertumpu pada otoritas ulama, maka saat ini cenderung bertumpu pada umara. Hukum-hukum agama yang akan diberlakukan dalam suatu negara, baru akan berlaku atau berjalan mulus manakala mendapat keputusan dari penguasa politik (umara). Karena itu, bisa dipahami jika hampir di seluruh dunia Islam, termasuk Somalia, kodifikasi, dan juga unifikasi menjadi agenda pembaruan hukum

${ }^{55}$ Kodifikasi hukum Islam pertama dengan paradigma Barat adalah Majallat al-Ahkam al-'Adliyyah yang lahir dari penguasa Turki Utsmani yang ditanda tangani pada tanggal 8 Zdulhijjah 1285/10 Maret 1869. Baca W.E. Grigsby, The Medjelle or Ottoman Civil Law (London: Stevens and Sons, t.t.).

56 Ann Elizabeth Mayer, "The Shari'ah: A Methodology or A Body of Substantive Rules?" Dalam Islamic Law and Jurisprudence, Nicholas Heer (ed.) (Seattle and London: University of Washington Press, 1990), 177. 
sekaligus menjadi topik yang hangat serta menjadi perhatian para ahli hukum Islam. ${ }^{57}$

Tentu saja, pada level praktis benturan tidak bisa dielakkan. Sebab penganut paham hukum Islam, sebagaimana fiqh pada masa klasik dan tengah, menuntut realisasi hukum justru menempatkan "perbedaan agama" sebagai salah satu unsure penting dalam konsep dan realisasi hukum, sedangkan kerangka hukum modern menempatkan manusia sama di depan hukum (equal before law), regardless of their origin, race, color, tradition, even religion. Di samping itu, paham klasik dan tengah hampir-hampir tidak memisahkan antara hukum dan moral, sedangkan konsep modern menghendaki pemisahan tegas antara keduanya.

Sebagaimana telah dijelaskan di atas, bahwa Somalia adalah negara yang mayoritas penduduknya menganut mazhab Syâfi'î. Meskipun demikian, dalam realitas empiris, pandangan-pandangan Syâfi'î tidak sepenuhnya mewarnai atau menjadi rujukan dalam pembuatan hukum keluarga. Khususnya dalam masalah warisan dimana hukum warisan Somalia nampak lebih revolosioner bila dibanding dengan negara-negara lainya. Ada beberapa hal yang melatar belakangi, diantaranya adalah karena faktor sosiologis negara tersebut, adanya empat tradisi hukum yang berkembang dan sistem pemerintahan yang sosialis, merupakan unsur-unsur lain yang ikut mempengarui pembentukan dan pembaruan hukum keluarga (personal status) di Somalia.

Somalia termasuk negara yang menerapkan hukum keluarga Islam dengan mengadakan pembaruan-pembaruan baik dari segi prosedural (hukum acara), struktur peradilan, maupun materi hukumnya. Tujuan dari reformasi hukum Somalia, tampaknya didasari atas semangat untuk melindungi hak-hak dan

57 Baca misalnya A. Qadri Azizy, Eklektisisme Hukum Nasional: Kompetisi Antara Hukum Islam dan Hukum Nasional (Yogyakarta: Gama Media, 2002). Lihat juga Minhaji, Hukum Islam: Antara Sakralitas dan Profanitas (Perspektif Sejarah Sosial), Pidato Pengukuhan Guru Besar Sejarah Sosial Pemikiran Hukum Islam pada Fakultas Syari'ah Tanggal 25 September (Yogyakarta: UIN, 2004), 37. 
meningkatkan derajad kaum wanita, tentunya disamping juga untuk mewujudkan unifikasi hukum dan merespons perubahan zaman. Dari sifat pembaruan yang dilakukan, jelas terlihat bahwa pembaruan hukum keluarga Somalia, meminjam istilah Tahir Mahmood, bersifat extra-doctrinal reform, yaitu dengan mengambil unsur-unsur di lauar hukum Islam sama sekali. Unsur-unsur tersebut diantaranya adalah ide "keadilan sosial" yang notabene-nya menjadi prinsip revolusi sosialis sekaligus menjadi semangat dalam pembentukan dan pembaruan hukum.

Dilihat dari metode yang digunakan, reformasi atau pembaruan hukum keluarga Somalia tampaknya mengintrodusir beberapa metode, yaitu: melalui "siyâsah syar'iyyah" (regulatory) yaitu lewat aturan yang bersifat prosedural (prosedur peradilan dan struktur pengadilan) serta penertiban administrasi. Unsur regulatori tersebut diadopsi dari sistem hukum Barat -terutama Anglo Saxon dan Italia- seperti adanya pemisahan hukum perdata dan pidana, tingkatan-tingkatan pengadilan dari tingkat distrik, regional, banding dan pengadilan tingkat tinggi.

Disamping itu, Somalia juga menggunakan metode ijtihad dengan jalan memberikan penafsiran yang sama sekali baru terhadap nash yang ada. Hal ini tercermin dalam materi hukum waris yang ada, diantaranya adalah pasal 158 dan 160 undang-undang No. 23 tahun 1975, sebagimana telah disebut di atas. Dalam pasal 158 dinyatakan bahwa laki-laki dan perempuan mempunyai hak yang sama dalam pembagian warisan. Sementara pasal 160 itu secara rinci juga mengatur bahwa isteri yang ditinggal mati suaminya mendapatkan separoh harta dari harta peninggalan jika tidak ada anak atau cucu, dan mendapatkan seperempat jika ada anak atau cucu.

Aturan tersebut jelas sekali berbeda dengan aturan yang ada dalam al-Qur'an yang menegaskan bahwa laki-laki mendapatkan 
bagian dua kali lipat dari bagian anak perempuan. ${ }^{58}$ Demikian juga dengan isteri yang mendapatkan seperempat dari harta peninggalan jika tidak ada anak dan mendapatkan seperdelapan jika ada anak. ${ }^{59}$

Secara umum dapat dilihat bahwa hukum waris Somalia di atas selain berbeda dengan aturan dalam al-Qur'an juga berbeda dengan aturan dari mainstream mazhab yang dianut, yakni mazhab Syafi'î secara khusus dan mazhab empat secara umum. Hal ini terjadi tentu tidak lepas dari tujuan, metode yang digunakan serta faktorfaktor yang mempengarui pembaruan hukum tersebut sebagaimana telah diuraikan sebelumnya.

Somalia juga meratifikasi hak asasi manusia internasional yang mana tidak menganut adanya pembedaan hak antara laki-laki dan perempuan. Persamaan hak ini sedikit banyak ikut mengilhami reformasi hukum keluarga, khususnya materi kewarisan Somalia, sehingga tidak mengherankan manakala terdapat pemberian hak yang sama antara ahli waris laki-laki dan ahli waris perempuan. Dalam konteks inilah telah terjadi perubahan besar (revolusioner) dalam konsep pembagian harta warisan di semua tingkat ahli waris, termasuk konsep ashabah, ${ }^{60}$ karena didasarkan atas persamaan hak tersebut.

Selanjutnya, menilik format atau model pembaruan yang diterapkan, tampak dengan jelas bahwa "kodifikasi" (doktrin siyâsah) adalah pilihan dari model atau format reformasi hukum keluarga yang sedang diaplikasikan di Somalia. Hal ini tentunya selaras dengan kecenderungan pembaruan hukum keluarga di negaranegara Islam pada umumnya.

58 Lihat QS. An-Nisâ' (4): 11.

59 Lihat QS. An-Nisâ' (4): 12.

${ }^{60}$ Dimana dalam konsep kewarisan Sunni ahli waris ashabah (bi nafsih) terdiri dari ahli waris laki-laki, namun dalam konsep ashabah hukum waris Somalia, ahli waris perempuan dapat menjadi ashabah bin nafsih. Ketentuan ini dapat dilihat dalam pasal 161 di atas. Penjelasan lebih jauh tentang ashabah binafsih, diantaranya bisa dilihat dalam bukunya Fatchur Rahman, Ilmu Waris (Bandung: PT al-Ma'arif, 1994), 340. 
Al-hasil, bahwa dalam pembaruan hukum keluarga Somalia, ada beberapa aturan yang tidak jauh berbeda dari konsep imam mazhab, tetapi ada pula beberapa aturan hukum yang cukup jauh beranjak dari konsep fikih konvensional, khususnya aturan hukum yang terkait dengan kewarisan.

\section{PENUTUP}

Dari paparan di atas dapat disimpulkan beberapa hal sebagai berikut: Pertama, meskipun dalam masalah keagamaan Somalia menganut mazhab Syâfi'î, namun dalam prakteknya pandanganpandangan Syâfi'î tidak sepenuhnya mewarnai atau menjadi rujukan dalam pembuatan dan pembaruan hukum, khususnya hukum waris. Kedua, Hukum waris Somalia tampak lebih revolusioner di banding negara-negara Islam lainnya. Hal ini karena pembaruan hukum Somalia dipengaruhi oleh beberapa tradisi sistem hukum yang berkembang, yaitu: Anglo Saxon, Eropha Kontinental, hukum Islam, dan hukum adat.

Ketiga, Reformasi materi hukum waris Somalia bersifat extradoctrinal reform dengan mengintrodusir metode siyâsah syar'iyyah (regulatory) dan ijtihad dengan cara reinterpretasi terhadap nas sesuai dengan tuntutan zaman. Sedangkan "kodifikasi" menjadi format atau model dari pembaruan hukum yang diterapkan. Keempat, Perubahan materi hukum waris -terutama dalam hal pembagian harta warisan- bertujuan untuk mengangkat derajad kaum wanita dengan jalan memberikan bagian yang sama antara laki-laki dengan perempuan. Hal ini didasarkan pada prinsip-prinsip revolusi sosialis yang yang menekankan pada aspek keadilan sosial dan persamaan hak asasi manusia. Ini berarti pula bahwa beberapa aturan perundang-undangan Somalia telah beranjak dari konsep tradisional sebagaimana termaktub dalam kitab-kitab fikih. Kelima, Usaha pembaruan Hukum Keluarga Muslim akan terus berlanjut sesui dengan tuntutan dan perkembangan zaman, terutama tuntutan yang datang dari gerakan emansipasi wanita. Wallâhu A'lam bi alShawwôb,! 


\section{BIBLIOGRAFI}

Al-Albani. Silsilah al-Hadîts al-Shahîh. Beirût-Libanon: al-Maktar alIslâmî, 1972.

Anderson, Benedict. Imagined Community: Reflections on the Origins and Spread of Nationalism. London: Verso, 1983.

Anderson, J.ND. Islamic Law in the Modern World. New York: New York University Press, 1975.

-------. Law Reform in the Muslim World. London: University of London Press, 1976.

-------. "Modern Trends in Islam: Legal Reform and Modernization in the Middle East", dalam International and Comparative Law Quarterly, 20 Januari, 1971.

An-Na'im, Abdullah Ahmed. Islamic Family Law in Changing World: A Global Resource Book. New York: Zed Book Ltd, 2002.

Azizy, A. Qadri. Eklektisme Hukum Nasional: Kompetensi antara Hukum Islam dan Hukum Umum. Yogyakarta: Gama Media, 2002.

Collin, Peter. Dictionary of Law. Peter Collin Publishing, 2000.

Coulson, Noel J. A History of Islamic Law. Edinburgh: Edinburgh University Press, 1964.

Echol, John M. (et.al). Kamus Inggris Indonesia. Jakarta: PT Gramedia, 2003.

Emerson, Rupert. From Empire to Nation: The Rise to Self-Assertaion of Asian and African Peoples. Boston: Beacon Press, 1963.

Esposito, John L. Women in Muslim Family Law. New York: Syracuse University Press, 2001.

------, (ed.). The Oxford Encyclopedia of the Modern Islamic World. New York: Oxford University Press, 1999.

Depdikbud. Kamus Besar Bahasa Indonesia. Jakarta: PN Balai Pustaka, 1990.

Gibb, H.A. R., (et.al., eds.). E.J. Brill's First Encyclopedia of Islam 19131936, Vol. VII. Leiden \& New York: Kobenhavn, 1987.

Glasse, Cyril. Ensiklopedi Islam. terj., Ghufron A. Mas'adi. Jakarta: PT Raja Grafindo Persada, 1999.

Hudson, C.RWS. "religious Life”, dalam http Somalia 
Inamullah, Khan (ed.). The World Muslim Gazetter. Delhi: International Islamic Publisher, 1992.

Rashid, Khalid (et.al., ed.). The Origins of Arab Nationalism. New York: Columbia University Press, 1991.

Mahmood, Tahir. Family Law Reform in the Muslim World. Tripathi, Bombay: The Indian Law Institute, 1971.

-------. Personal Law in Islamic Countries. New Delhi: Academy of Law and Religion, 1987.

Ma'luf, Louis. Al-Munjid al-Abjadî. Beirût: Dâr al-Masyriq, 1986.

Mayer, Ann Elizabeth. " The Shari'a: A Methodology or Body of Substantive Rules?" Dalam Islamic Law and Jurisprudence. Nicholas Heer (ed.). Seattle and London: University of Washington Press, 1990.

Minhaji, Akh. Hukum Islam: Antara Sakralitas dan Profanitas (Perspektif Sejarah Sosial). Yogyakarta: UIN-SUKA, 2004.

Mu'allim, Amir \& Yusdani. Konfigurasi Pemikiran Hukum Islam. Yogyakarta: UII Press, 2001.

Mudzhar, M. Atho'. Fatwa-Fatwa Majlis Ulama Indonesia: Sebuah Studi tentang Pemikiran Hukum Islam di Indonesia 1975-1988. Jakarta: INIS, 1993.

--------. Membaca Gelombang Ijtihad: Antara Tradisi dan Litersi, Yogyakarta: Titian Ilahi Press, 1998.

--------, et.al., (ed.). Hukum Keluarga di Dunia Islam Modern: Studi Perbandingan dan Keberanjakan UU Modern dari Kitab-Kitab Fiqh, Jakarta: Ciputat Press, 2003.

Nasution, Harun. Pembaruan Hukum Islam: Pemikiran dan Gerakan. Jakarta: Bulan Bintang, 1986.

Nasution, Khoiruddin. Status Wanita di Asia Tenggara: Studi terhadap Perundang-Undangan Perkawinan di Indonesia dan Malaysia. Jakarta: INIS, 2002.

Noeh, Zaini Ahmad. "Perkembangan setelah Undang-Undang Perkawinan," dalam Daniel S. Lev, Peradilan Agama Islam di Indonesia: Suatu Studi Landasan Politik Lembaga-Lembaga Hukum. Jakarta: Intermasa, 1986. 
Pearl, David, (et.al.). Muslim Family Law. London: Sweet \& Maxwell, 1998.

Ramusack, Barbara, (et.al.). Women in Asia. Indianapolis: Indiana University Press, 1988.

Rafiq, Ahmad. Pembaruan Hukum Islam di Indonesia. Yogyakarta: Gama Media, 2001.

Saad, Bustami Muhammad. Mafhûm Tajdîd al-Dîn al-Da'wah. Kuwait: $\mathrm{ttp}, \mathrm{tt}$.

Zuhdi, Masjfuk. Pembaruan Hukum Islam dan Kompilasi Hukum. Surabaya: PTA Jawa Timur, 1995. 